\title{
The Development of a Sport-based Personal and Social Responsibility Intervention on Daily Violence in Schools
}

\author{
Bernardino Javier Sánchez-Alcaraz Martínez ${ }^{1, *}$, Alberto Gómez-Mármol ${ }^{2}$, Alfonso Valero Valenzuela ${ }^{3}$, \\ Ernesto De la Cruz Sánchez ${ }^{3}$, Arturo Díaz Suárez ${ }^{3}$ \\ ${ }^{1}$ Physical Education Department, IES Samaniego, Murcia, España \\ ${ }^{2}$ Faculty of Education, University of Murcia, Murcia, España \\ ${ }^{3}$ Faculty of Sport Sciences, University of Murcia, Murcia, España \\ *Corresponding author: bjavier.sanchez@um.es
}

Received November 20, 2014; Revised December 15, 2014; Accepted December 25, 2014

\begin{abstract}
This research assess the improvements that the implementation of Personal and Social Responsibility Model produces on observed and suffered violence among teenagers. In order to this, a training course was taught to 9 teachers (5 from primary school and 4 from secondary school), who implementated the Responsibility Model during 24 Physical Education lessons. The participants, 215 students from primary education and 189 from secondary education, were divided on 9 control groups and 9 experimental groups. Postest results point that observed violence as well as suffered violence improved significantly on experimental groups, in contrast to control groups, where there were not significant differences in any of both variables. Therefore, Personal and Social Responsibility Model is an efficient teaching methodology to improve the quotidian scholar violence in Physical Education lessons.
\end{abstract}

Keywords: education in values, violence, students

Cite This Article: Bernardino Javier Sánchez-Alcaraz Martínez, Alberto Gómez-Mármol, Alfonso Valero Valenzuela, Ernesto De la Cruz Sánchez, and Arturo Díaz Suárez, "The Development of a Sport-based Personal and Social Responsibility Intervention on Daily Violence in Schools." vol. 2, no. 6A (2014): 13-17. doi: 10.12691/ajssm-2-6A-4.

\section{Introduction}

Since last years, scholar violence has become a serious problem at educative centres, creating conflictive atmosphere and relationships, inadequates to learning and personal and social development, due to the lack of the required competences to solve peacefully the aformentioned conflicts [1].

This phenomenon has been called quotidian violence among equals [2], referring to those contexts that are characterized by interpersonal relationships that solve their conflicts through unjustified aggressive conducts, mainly mutual and among students, that are often insults, physical aggressions, social exclusions or threatens; coexisting two types, depending on wether the violence has been observed or suffered [3].

Different studies point a progressive increase of aggressiveness and antisocial and violent behaviours from primary education and secondary education until 15-16 years old, when there is a decrease of impulsiveness and values and rules are embraced [4].

In this way, Physical Education lessons and Scholar Sport represent an educative field where their environment and the activities they involve, allow to create very open interpersonal relationships among equals as well as with their teachers, offering the opportunity to show tangibly and instantaneously personal and social skills that in other scholar context could result much more difficult to show $[5,6]$.

Considering these data, during last decades, important efforts have been devoted to design and develope intervention programs in order to develope possitive behaviours (responsibility, self-control, leadership, selfconcept, authonomy, etc.) and to decrease violent or negative behaviours [7-12].

One of the programs that has had the best results is Personal and Social Responsibility Model by Hellison (2003). This model was designed, initially, with the aim that teenagers and youngs at risk lived success experiences that ease the development of their personal and social skills, as much in sport as in life. Personal and Social Responsibility Model (PSRM) hold the need of teaching behaviours and values that improve the life of the students through sport. In this way, Hellison (2003), associates two values to personal wellness and development: effort and self-management, and other two values to social integration and development: respect for other feelings and rights; and the skill to listen and put theirselves on other place [13].

The central core of PSRM is that students, in order to be efficient in their environment individuals, have to learn to be responsible of themselves and others and incorporate the strategies that let them exercise the control of their lifes [6]. To carry out this learning, Hellison (2003), 
proposes five responsibility levels: Level 1, respect for others' feelings and rights; Level 2, effort; Level 3, authonomy; Level 4, help and caring for others; and Level 5 , transfering the learnings to other context out of the program. These levels, that are showed to students progressively and cumulatively, define behaviours, attitudes and personal and social values [5] to be developed through physical activity and sport from concrete and simple goals. For each level, there is a sort of specific strategies and methods to e developed by students and teachers, so they can reach the goals they aim in each level of PSRM.

Different researchers $[6,9,14,15,16,17,18]$ have pointed through numerous researches how the implementation of PSRM has developed aspects related with Personal and Social Responsibility, like respect, self-control, selfesteem, effort, self-concept, wellness feeling, emotional stability, authonomy or leadership, at Physical Education lessons and other contexts like familiar, educative or sport [6], as well as a decrease of anxiety, depression or stress perception [5,6]. Additionally, other studies have demonstrated how, after the implementation of the model, there were significant improvements in violent and nonsportmanship behaviours $[9,18]$.

Therefore, the main goal of this research is to diminish the levels of observed and suffered scholar violence on students through the implementation of PSRM in Physical Education lessons.

\section{Methodology}

\subsection{Participants}

The sample was made up by 404 students, 215 from sixth grade of primary education (129 boys and 86 girls) and 189 from third grade of secondary education (100 boys and 89 girls) whose mean ages were $12.26 \pm 0.71$ years old and $15.43 \pm 0.84$ years old respectively. The selection of the educative centres has been done according to the geographic division of the Teachers and Resources Centre of the Region of Murcia, so each one of the nine centres participated with one primary school or one secondary school.

\subsection{Instruments}

Scholar violence. The Quotidian Scholar Violence was designed from California School Climate and Safety Survey (CSCSS) by Rossenblatt and Furlong [19]. From this version, Fernández-Baena et al. [3] chose 14 items that were conceptually adequate to assess scholar violence among equals, including suffered violence (for instance: "I have been punched or kicked") and observed violence (for instance: "students get involved in fights"). Items are presented in 5 options Likert scale, from 1 (never) to 5 (always).

\subsection{Procedures}

The sample was randomly divided into two groups: experimental group ( $\mathrm{n}=198,116$ boys and 82 girls $)$ and control group ( $n=206,113$ boys and 93 girls). Experimental groups' teachers participated in a training course about the implementation of PSRM, whose duration was 30 hours, divided into 5 lessons. This course, that was taught by specialized in this model speakers, provided the needed tools to adapt the traditional teaching of Physical Education contents to new pedagogical strategies and to create new curricular material specific of PSRM.

Once the teachers formation was ended, pretest was developed in all centres, in experimental and control groups, where the quotidian scholar violence questionnaire was administrated, reminding the anonymity of the answers. Then, experimental groups' teachers implemented PSRM during 4 months (24 lessons); meanwhile, control groups' teachers kept on with their habitual methodology. Within the intervention period, 4 following meetings were celebrated, with a total duration of 20 hours, to ensure that teachers were implementing PSRM adequately. When the invertention period ended, postest was developed, administrating the quotidian scholar violence questionnaire during Physical Education lessons.

\section{Results}

\subsection{Psychometric properties of Quotidian Scholar Violence Questionnaire}

Table 1. Descriptive statistics and intern consistency

\begin{tabular}{|c|c|c|c|c|c|c|}
\hline Scale & M & $\mathrm{SD}$ & TICC-c & $\alpha$ without item & As & $\mathrm{Ku}$ \\
\hline \multicolumn{7}{|l|}{ Suffered violence } \\
\hline 1. I have been pushed & 2.25 & 1.21 & .51 & .87 & .64 & -.50 \\
\hline 2. I have been punched or kicked & 1.60 & .97 & .57 & .87 & 1.67 & 2.25 \\
\hline 3. I have been hit with an object & 1.43 & .79 & .48 & .87 & 1.90 & 2.91 \\
\hline 4. I have been stolen & 1.63 & .94 & .49 & .87 & 1.88 & 3.09 \\
\hline 5. I have been said I was going to be hit & 1.42 & .91 & .57 & .87 & 2.04 & 5.51 \\
\hline 6. Someone broke any of my things & 1.44 & .84 & .59 & .87 & 2.09 & 4.07 \\
\hline 7. I have been threatened & 1.37 & .82 & .60 & .86 & 2.54 & 6.36 \\
\hline 8. I have been mocked & 1.59 & 1.02 & .53 & .87 & 1.88 & 2.92 \\
\hline \multicolumn{7}{|l|}{ Observed violence } \\
\hline 9. Students use drugs & 1.51 & 1.02 & .47 & .87 & 1.99 & 3.03 \\
\hline 10. Students destroy things & 2.05 & 1.15 & .61 & .86 & .86 & -.103 \\
\hline 11. Students get involved in fights & 2.55 & 1.28 & .53 & .87 & .39 & -.90 \\
\hline 12. Students steal things & 2.02 & 1.15 & .61 & .86 & .83 & -.33 \\
\hline 13. Students theraten other students & 2.41 & 1.32 & .66 & .86 & .48 & -.92 \\
\hline 14. Students insult other students & 3.38 & 1.44 & .48 & .87 & -.39 & -1.14 \\
\hline
\end{tabular}

Note: As: Asymmetry; Cu: Kurtosis; TICC-c: total-item corrected coefficient correlation; $\alpha$ without item: scale Cronbach's alpha removing the item. 
Firstly, the characteristics of the questionnaire items were analyzed using the whole sample (Table 1), checking if alpha scale increased after removing any item as well as considering Nunnally and Bernstein [20] recommendations to keep a item incide a factor: total-item corrected coefficient correlation (TICC-c) $\geq .30$ and asymmetry index between 2 and -2 . On the other side, total scale reported a Cronbach's Alpha of .87 , considered as very acceptable for this type of questionnaires, and similar to the value found by Fernández-Baena et al. [3] in the instrument validation article.

In order to know the suitability of the use of Quotidian Scholar Violence Questionnaire, exploratory factor análisis was done, ratifying the initial proposal of Rossenblatt and Furlong [19], that groups the items into two factors, this is, observed violence and suffered violence (Table 2).

Table 2. Obtained factors and items saturation in the factor

\begin{tabular}{lcll}
\hline Suffered violence & Saturation & Observed violence \\
\hline 1. I have been pushed & .48 & 9 . Students use drugs \\
2. I have been punched or kicked & .62 & 10 . Students destroy things \\
3. I have been hit with an object & .49 & 11 . Students get involved in fights \\
4. I have been stolen & .61 & 12. Students steal things \\
5. I have been said I was going to be hit & .69 & 13. Students theraten other students \\
6. Someone broke any of my things & .62 & 14 . Students insult other students \\
7. I have been threatened & .73 & \\
8. I have been mocked & .64 & \\
\hline
\end{tabular}

\subsection{Effects of PSRM Implementation on Levels of Quotidian Scholar Violence}

In order to determine the changes that PSRM has produced, T test for two related samples was developed.
There were significant decreases on levels of observed and suffered violence in experimental groups, meanwhile there were not differences on any variable in control groups (Table 3).

Table 3. Effects of PSRM implementation on the whole sample

\begin{tabular}{|c|c|c|c|c|c|c|c|}
\hline \multirow{2}{*}{ Type of violence } & \multicolumn{3}{|c|}{ Pretest } & \multicolumn{3}{|c|}{ Postest } & \multirow[b]{2}{*}{ Sig. } \\
\hline & Type of participation & M & SD & Type of participation & M & $\mathrm{SD}$ & \\
\hline \multirow{2}{*}{ Suffered violence } & Control & 1.55 & .66 & Control & 1.54 & .68 & .481 \\
\hline & Experim. & 1.60 & .63 & Experim. & 1.39 & .76 & $.037 *$ \\
\hline \multirow{2}{*}{ Observed violence } & Control & 2.14 & .88 & Control & 2.29 & 1.01 & .104 \\
\hline & Experim. & 2.50 & .89 & Experim. & 2.34 & .99 & $.035^{*}$ \\
\hline
\end{tabular}

$*$ The difference has a significant level of $\mathrm{p}<.05$

Next, the levels of observed and suffered violence before and after the PSRM implementation are presented, for primary control groups and primary experimental groups as well (Table 4). For suffered violence, initial values are higher in control group with respect to experimental groups meanwhile for observed violence, this relationship is inverted.

Table 4. Effects of PSRM implementation on Primary students

\begin{tabular}{|c|c|c|c|c|c|c|c|}
\hline \multirow{2}{*}{ Type of violence } & \multicolumn{3}{|c|}{ Pretest } & \multicolumn{3}{|c|}{ Postest } & \multirow[b]{2}{*}{ Sig. } \\
\hline & Type of participation & M & $\mathrm{SD}$ & Type of participation & M & $\mathrm{SD}$ & \\
\hline \multirow{2}{*}{ Suffered violence } & Control & 1.77 & .77 & Control & 1.69 & .77 & .633 \\
\hline & Experim. & 1.69 & .74 & Experim. & 1.64 & .81 & $.024 *$ \\
\hline \multirow{2}{*}{ Observed violence } & Control & 2.06 & .91 & Control & 2.27 & 1.00 & .094 \\
\hline & Experim. & 2.56 & .91 & Experim. & 2.19 & .91 & $.001 * *$ \\
\hline
\end{tabular}

* The difference has a significant level of $\mathrm{p}<.05$

** The difference has a significant level of $\mathrm{p}<.01$.

Analogously, this same statistic test has been done for secondary students obtaining the results presented at Table 5. In this case, pretest values, in suffered violence and observed violence, are higher in control group with respect to experimental group, in contrast to primary students; however, the main difference between primary

and secondary students is the effects of PSRM implementation to the extent that on secondary students it supposes a non-significant low increase in observed violence. As against, suffered violence does have a low significant decrease after PSRM implementation.

Table 5. Effects of PSRM implementation on Secondary students

\begin{tabular}{|c|c|c|c|c|c|c|c|}
\hline \multirow{2}{*}{ Type of violence } & \multicolumn{3}{|c|}{ Pretest } & \multicolumn{3}{|c|}{ Postest } & \multirow[b]{2}{*}{ Sig. } \\
\hline & Type of participation & M & SD & Type of participation & M & $\mathrm{SD}$ & \\
\hline \multirow{2}{*}{ Suffered violence } & Control & 1.51 & .48 & Control & 1.56 & .72 & .576 \\
\hline & Experim. & 1.42 & .49 & Experim. & 1.37 & .53 & $.043 *$ \\
\hline \multirow{2}{*}{ Observed violence } & Control & 2.44 & .87 & Control & 2.52 & 1.06 & .733 \\
\hline & Experim. & 2.25 & .85 & Experim. & 2.33 & 1.03 & .587 \\
\hline
\end{tabular}

* The difference has a significant level of $\mathrm{p}<.05$

Finally, regarding the sex of participants, U Mann Whitney test has demonstrated that the intervention of this research has produced improvements on suffered violence
( $p=.021 ; Z=-2.316)$. These values have been higher on men $(\mathrm{M}=1.65 ; \mathrm{SD}=0.77)$ than on women $(\mathrm{M}=1.47$; $\mathrm{SD}$ $=0.65)$. 


\section{Discussion and Conclusions}

Regarding the first goal of this research, it could be confirmed that Personal and Social Responsibility Model is being considered as an adequate tool to reduce scholar violence in Physical Education lessons, within a short term.

In this way, after 24 Physical Education lessons where PSRM was implemented, significant improvements for experimental groups in observed and suffered violence were appreciated. These improvements coincide with the attached results of other studies about PSRM [9,18] or other similar Education in Values Models [21-26].

Initial data have shown higher levels of observed and suffered violence on secondary students, ratifying the conclusions of other studies about scholar violence $[4,27,28]$, as well as lower values on girls, according to the researches developed by Fernández-Baena et al. [3] and Martínez-Monteagudo et al. [2], who found higher levels of scholar violence among boys.

On the other side, the improvements of PSRM implementation were higher on primary groups with regard to secondary groups, although it is true that secondary students had higher values for observed and suffered violence, coinciding with Felip and Capell's [29] data, who afirm that physical aggressions take place almost always, in secondary schools.

With regard to the sex, the treatment has shown improvements on suffered violence, more noticeable on boys than on girls, in contrast to Trianes, De la Morena, Infante and Raya [30] study, who obtained higher levels on girls, but similar to Fernández-Baena et al. [3] study, who obtained higher values on boys indeed.

Therefore, Personal and Social Responsibility Model is an efficient methodology to educate in values and to improve the coexistence, decreasing the levels of violence, suffered and observed, among young scholars; a collective who needs everyday with more urgency the implementation of programs like the one used on the present research.

Finally, there are some limitations on this research as a consequence of the treatment duration (three months) despite of being similar to other studies [31,32]. In this way, other researches have reached better improvements having implemented the PSRM for more time, what allowed teachers to spend more time to develope each level of personal and social responsibility $[33,34]$. Therefore, some of the future works proposed suggest the reduction of the number of participant centres at the same time that the increase of the intervention duration (a whole academic year). This has a double aim: on one side, having a more exhaustive control of the implementation, through periodical lessons reports, and, on the other side, considering other type of variables that could be related with education in values and violence, as sportpersonship or responsibility [35].

\section{References}

[1] Palou, P., Ponseti, X. and Borras, P.A. "Hábitos deportivos de los estudiantes de la Universidad de las Islas Baleares". Educación y Cultura, 14, 163-180. 2001.

[2] Martínez-Monteagudo, M., Inglés, C.J., Trianes M.V. and GarcíaFernández, J.M. "Perfiles de ansiedad escolar: Diferencias en clima social y violencia entre iguales". Electronic Journal of Research in Educational Psychology, 9 (3), 1023-1042. 2011.

[3] Fernández-Baena, F.J., Trianes, M.V., De la Morena, M.L., Escobar, M., Infante, L. and Blanca, M.J. "Propiedades psicométricas de un cuestionario para la evaluación de la violencia cotidiana entre iguales en el contexto escolar". Anales de psicología, 27 (1), 102-108. 2011.

[4] Döpfner, M., Pluck, J. and Lehrnkuhl, G. Aggressivitat und Dissozialitat von Kindern und Jugendlichen in Deutschland. Harnburg: Brigitte. 1996.

[5] Escartí, A., Pascual, C. and Gutiérrez, M. Responsabilidad Personal y Social a través de la educación física y el deporte. Barcelona: Graó. 2005.

[6] Hellison, D. Teaching responsibility through physical activity (2 ed.). Champaign, IL: Human Kinetics. 2003.

[7] Balibrea, E., Santos, A. and Lerma, I. "Actividad física, deporte e inserción social: un estudio exploratorio sobre los jóvenes en barrios desfavorecidos". Apunts, Educación Física y Deportes, 69, 106-111. 2002.

[8] Cecchini, J.A., Fernández, J., González, C. and Arruza, J.A. "Repercusiones del programa delfos de educación en valores a través del deporte en jóvenes escolares". Revista de Educación, 346, 167-186. 2008.

[9] Cecchini, J.A., Montero, J. and Peña, J.V. "Repercusiones del programa de intervención para desarrollar la responsabilidad personal y social de Hellison sobre los comportamientos de fairplay y el auto-control". Psicothema, 15, 631-637. 2003.

[10] Durán, J., Gómez, V., Rodríguez, J.L. and Jiménez, P. "La Actividad Física y el Deporte como medio de integración social y de prevención de violencia: programa educativo con jóvenes socialmente desfavorecidos". I Congreso de la Asociación Española de Ciencias del Deporte. Universidad de Extremadura: Facultad de Ciencias del Deporte, pp. 405-414. 2000.

[11] Ennis, C.D. "Creating a culturally relevant curriculum for disengaged girls". Sport, Education and Society, 4, 31-49. 1999.

[12] Ruiz, L.M., Rodríguez, P., Martinek, T., Schilling, T., Durán, L.J. and Jiménez, P. "El proyecto esfuerzo: un modelo para el desarrollo de la responsabilidad personal y social a través del deporte". Revista de Educación, 341, 933-958. 2006

[13] Escartí, A., Gutiérrez, M., Pascual, C. and Marín, D. “Aplication of Hellison's Teaching Personal and Social Responability Model in Physical Education to improve Self-Efficacy for Adolescents at Risk of Dropping-out of School". The Spanish Journal of Psychology, 13 (2), 667-676. 2010.

[14] Martinek, T. and Hellison, D. "Fostering resiliency in underserved youth through physical activity". Quest, 49, 34-49. 1997.

[15] Jiménez-Martín, P.J. and Durán, L.J. "Propuesta de un programa para educar en valores a través de la actividad física y el deporte". Apunts, Educación Física y Deportes, 77, 25-29. 204.

[16] Jiménez-Martín, P.J. and Durán, L.J. “Actividad física y deporte en jóvenes en riesgo: educación en valores". Apunts, Educación Física y Deportes, 80, 13-19. 2005.

[17] Martinek, T., McLaughlin, D. and Schilling, T. "Project effort: Teaching responsibility beyond the gym". Journal of Physical Education, Recreation and Dance, 70, 59-66. 1999.

[18] Cecchini, J.A., Montero, J., Alonso, A., Izquierdo, M. and Contreras, O.R. "Effects of personal and social responsability on fair play in sports and self-control in school-aged youths". European Journal of Sport Science, 7 (4), 203-211. 2007.

[19] Rosenblatt, J. and Furlong, M.J. "Assessing the reliability and validity of student self-reports of campus violence". Journal of Youth and Adolescence, 26, 187-201. 1997.

[20] Nunnally, J.C. and Bernstein, I.J. Teoría Psicométrica. Madrid: McGraw-Hill. 1995

[21] Bredemeier, B. "Children's moral reasoning and their assertive, aggressive, and submissive tendencies in sport and daily life". Journal of Sport \& Exercise Psychology (JSEP), 16 (1), 1-14. 1994

[22] Cruz, J., Boixadós, M., Valiente, L. and Torregrosa, M. “¿Se pierde el "fairplay" y la deportividad en el deporte en edad escolar?”. Apunts. Educación Física y Deportes, 64, 6-16. 2001.

[23] Cecchini, J.A., González, C., Alonso, C., Barreal, J.M., Fernández, C., García, M., Llaneza, R. and Nuño, P. "Repercusiones del Programa Delfos sobre los niveles de agresividad en el deporte y otros contextos de la vida diaria”. Apunts. Educación Física y Deportes, 96 (2), 34-41. 2009.

[24] Gibbons, S.L. and Ebbeck, V. "The effect of different teaching strategies on the moral development of physical education 
students". Journal of Teaching in Physical Education, 17, 85-98. 1997.

[25] Palau, P., Borras, P.A., Ponseti, F.. Vidal, J. \& Torregrosa, M "Intervención para la promoción de actitudes de fairplay en futbolistas cadetes". Apunts, Educación Física y Deportes, 89, 15 22. 2007.

[26] Romance, T. A Program to Promote Moral Development Through Elementary School Physical Education, Tesis Doctoral Inédita. Eugene. Universidad de Oregón. 1984.

[27] Fuchs, M., Lamnek, S. and Luedtkel, J. Schule und Gewalt. Realität und Wahrnehmung eines sozialen Problems. Opladen: Leske \& Budrich. 1996.

[28] González-Pérez, J. La violencia escolar: Un cáncer que afecta a las sociedades desarrolladas. En J.J. Gázquez, M.C. Pérez, A.J. Cangas and N. Yuste (Eds.). Situación actual y características de la violencia escolar. Granada: Grupo Editorial Universitario. 2007.

[29] Felip, N. and Capell, D. Una visión panorámica de la mejora de la convivencia en Educación Primaria en Catalunya. En J.J. Gázquez, and M.C. Pérez (Coords.), La Convivencia escolar. Aspectos Psicológicos y Educativos. Madrid: Editorial CEU. 2010.
[30] Trianes, M.V., De la Morena, B., Infante, L. and Raya, S. "Un cuestionario para evaluar el clima social del centro escolar". Psicothema, 18 (2), 272-277. 2006.

[31] Georgiadis, N. "Does basketball have to be all W's and L's? An alternative program at a residential boys' home". Journal of Physical Education, Recreation and Dance, 61 (6), 42-43. 1991.

[32] Escartí, A., Gutiérrez, M., Pascual, C., Marín, D., Martínez, C. and Chacón, Y. "Enseñando responsabilidad personal y social a un grupo de adolescentes de riesgo: un estudio observacional". Revista de Educación, 341, 373-396. 2006.

[33] Cutforth, N. "Connecting school physical education to the community through service-learning". Journal of Physical Education, Recreation and Dance, 71 (2), 39-45. 2000.

[34] Schilling, T. "An investigation of commitment among participants in an extended day physical activity program". Research Quarterly for Exercise and Sport, 72 (4), 355-365. 2001.

[35] Sánchez-Alcaraz, B.J., Díaz, A. and Valero, A. Mejora de la Convivencia Escolar a través de la Educación Física. El Modelo de Responsabilidad Personal y Social. Saarbrücken: Editorial Académica Española. 2014. 